\title{
PENGARUH PROGRAM PENGALAMAN LAPANGAN TERHADAP PENINGKATAN KOMPETENSI GURU PADA MAHASISWA PROGRAM PENDIDIKAN AKUNTANSI
}

\author{
Faqih Samlawi, Leni Yuliyanti
}

\begin{abstract}
The aim of this study was to obtain information regarding the competence of students teachers at the beginning and at the end of the implementation Field Experience Program. (FEP) of Pre-service teacher education process improvement.

The method used is a quasi experiment with the design of a one-group pretest - posttest design. From a population of 70 students of Force Accounting 2009, which implemient the FEP selected sample of 60 people. The data obtained through the study of the documentation of assessment from supervisor teacher.

The results showed that the activities of PPL improve the competence of Pre-service teachers from satisfactory to very satisfactory levels. Pedagogical activities at the beginning of FEP reached an average FEP of 3.02, whereas at the end of the FEP FEP achieved an average of 3.80. As for the professional competence of the average initial FEP of 2.71 and the final FEP changed to 3.86 .

Element of personality and social competence can not be tested because no differences befor after initial assessment at FEP or only the post - test FEPS. However, the FEP of personal competence posttest reached 3.86; achieve social competence as well as the post - test FEP 3.84 predictably very high FEP category.
\end{abstract}

Keywords: Field Experience Program, pedagogical, professional competence, personal competence and social competence.

\section{PENDAHULUAN}

Guru dihasilkan oleh Lembaga Pendidikan Tenaga Kependidikan (LPTK). Menurut Sunaryo dalam Kompas (2013) terdapat 427 PTK di negara kita termasuk 39 di antaranya adalah perguruan tinggi negeri. Universitas Pendidikan Indonesia yang merupakan sebagai merupakan LPTK yang tertua dan menurut beberapa hasil survey marupakan salah satu dari sepuluh perguruan tinggi terbaik di Indonesia.

Salah satu bagian dari kurikulum LPTK adalah program pengalaman lapangan (PPL). PPL merupakan muara dari semua proses pembentukan kompetensi berbasis kampus yaitu sejumlah mata kuliah selain PPL yang ada dalam Kurikulum UPI. Meskipun sebenarnya selama perkuliahan di Kampus, mahasiswa diberi tugas ke lapangan atau sekolah untuk mengobservasi kegiatan pembelajaran di kelas-kelas yang memiliki tujuan untuk mengenal lapangan sebagai pengejawantahan dari prinsip keterkaitan kampus dengan sekolah (university-school linkage).

Sementara itu, PPL merupakan pembentukan kompetensi guru yang berbasis lapangan yakni sekolah tempat dilaksanakan PPL hal mana mahasiswa sepenuhnya berada di sekolah (block system) dan tidak diperbolehkan mengontrak mata kuliah selain PPL. Menurut Guyton (1990) terdapat tiga hal terkait dengan program pengalaman lapangan yaitu kurikulum perguruan tinggi LPTK, proses supervisi dalam PPL, dan hasil dari praktek mengajar (student teaching). Pelaksanaan PPL merupakan keterpaduan dari ketiga aspek yang dipaparkan Guyton karena pelaksaannya merupakan bagian dari kurikulum LPTK, pembimbingan latihan mengajar dan kegiatan lainnya terhadap mahasiswa merupakan inti dari proses PPL dan hasil dari PPL itu sendiri berupa terbentuknya kompetensi guru.

Namun, dalam praktek pelaksanaan PPL terutama dalam pembentukan kompetensi guru seperti kompetensi pedagogis, kompetensi profesional, kompetensi sosial dan kompetensi kepribadian terdapat kendala - kendala yang dihadapi oleh dosen pembimbing, dosen luar biasa, dan mahasiswa pada waktu pelaksanaan PPL sehingga dapat menghambat proses pembenukan kompetensi guru. Terutama bagi program studi Pendidikan Akuntansi selama ini kurang sekali informasi yang komprehensif dari proses PPL mengenai gambaran kompetensi guru pada mahasiswa peserta PPL sebagai feed back hasil pendidikan berbasis kampus selama ini, juga sebagai bahan masukan bagi peningkatan mutu proses di program studi Pendidikan Akuntansi.

Menurut Undang-undang Republik Indonesia Nomor 14 Tahun 2005 tentang Guru dan Dosen sebagaimana tercantum dalam Penjelasan Peraturan Pemerintah No. 19 Tahun 2005 tentang Standar Nasional Pendidikan dikatakan bahwa "Seorang guru berkompeten apabila menguasai kompetensi pedagogik, kompetensi kepribadian, kompetensi profesional dan kompetensi sosial". Oleh karena itu, UPI sebagai lembaga pendidikan pencetak guru berkompeten menyiapkan para mahasiswa sebagai calon guru dengan membekali keempat kompetensi tersebut tidak hanya di kampus tetapi juga membetuk pengalaman dunia nyata dengtan mempraktekkan kompetensi profesional dan membentuk kompetensi paedagogis secara utuh. Demikian pula halnya dengan kompetensi sosial dan kompetensi kepribadian mahasiswa calon guru dibentuk secara utuh melalui kegiatan PPL. Mulai tahun 2011 berubah kembali menjadi PPL di bawah Divisi Pendidikan Profesi dan Jasa Keprofesian (P2JK).

Dengan adanya permasalahan yang sering dihadapi pihak-pihak terkait dalam pelaksaan PPL, maka penulis mempunyai keinginan untuk melihat apakah Program Pengalaman Lapangan mempunyai pengaruh terhadap kompetensi mengajar mahasiswa. Maka penulis bermaksud untuk mengangkat masalah dengan judul "Pengaruh Program Pengalaman Lapangan Terhadap Kompetensi Guru pada Mahasiswa Program Studi Pendidikan Akuntansi". 


\section{Rumusan Masalah}

Berdasarkan latar belakang masalah yang telah diuraikan diatas, maka rumusan masalah penelitian ini yaitu:

a. Bagaimana pengaruh Program Pengalaman Lapangan terhadap peningkatan kompetensi pedagogik pada mahasiswa Program Studi Pendidikan Akuntansi.

b. Bagaimana pengaruh Program Pengalaman Lapangan terhadap peningkatan kompetensi profesional pada mahasiswa Program Studi Pendidikan Akuntansi.

c. Bagaimana gambaran kompetensi kepribadian mahasiswa Program Studi Pendidikan Akuntansi dalam kegiatan Program Pengalaman Lapangan.

d. Bagaimana gambaran kompetensi sosial mahasiswa Program Studi Pendidikan Akuntansi dalam kegiatan Program Pengalaman Lapangan.

\section{Landasan Teori, KerangkaPemikiran, Penelitian Terdahulu dan Hipotesis}

Program Pengalaman Lapangan (PPL) menurut K.Wardani dan Anah Suhaenah Suparno (1994:1) adalah muara dari seluruh program pendidikan yang dihayatinya sepanjang masa belajarnya. Ini berarti, semua kegiatan baik yang diselenggarakan dalam bentuk kuliah, praktek, maupun kegiatan mandiri, diarahkan bagi terbentuknya kemampuan mengajar, yang secara terjadwal dan sistematis dibina pembentukkannya pada program pengalaman lapangan. Sementara itu, Program Pengalaman Lapangan (PPL) menurut buku panduan PPL yang dikeluarkan oleh Divisi P2JK (2013:1) adalah sebagai berikut:

Program Pengalaman Lapangan merupakan bagian integral dari proses pendidikan pada jenjang S-1 kependidikan yang dimaksudkan untuk menyediakan pengalaman belajar kepada mahasiswa dalam situasi nyata di lapangan dalam upaya mencapai kompetensi yang secara utuh telah ditetapkan oleh masing-masing program studi di lingkungan UPI.

Para ahli pendidikan terkemuka seperti Conant, Andrew menggambarkan Program Pengalaman Lapang (PPL) sebagai elemen paling penting dalam pendidikan profesi guru dan praktek mengajar merupakan mata kuliah yang paling disepakati secara universal sebagai yang paling penting dalam pembentukan kompetensi guru (Guyton dan Mclntyre; 1990: 514).

Berdasarkan uraian di atas dapat disimpulkan bahwa program pengalaman lapangan merupakan suatu program pendidikan yang dirancang dalam upaya pencapaian kompetensi mengajar untuk menyiapkan para mahasiswa sebagai calon guru yang profesional.

Pada dasarnya kompetensi guru untuk mahasiswa atau guru pra-jabatan mengacu pada kompetensi guru yang telah ditetapkan dalam Undang-undang Nomor14 Tahun 2005 yang meliputi empat kompetensi yaitu kompetensi pedagogik, kompetensi profesional, kompetensi kepribadian, dan kompetensi sosial.

Untuk mengetahui ketercapain kompetensi guru, mahasiswa LPTK wajib mengikuti Program Pengalaman Lapangan (PPL). PPL sebagai suatu program dalam pendidikan prajabatan guru yang dirancang khusus untuk menyiapkan para calon guru untuk menguasai kemampuan keguruan, sehingga setelah menyelesaikan pendidikan dan diangkat menjadi guru, para calon guru siap untuk mengemban tugas dan tanggung jawab sebagai guru.

Charters dan Waples mengidentifikasi kegiatan tugas-tugas guru melalui survey nasional yang menjadi rujukan kurikulum LPTK di Amerika (Cruickshank dan Metcalf: 1990: 471). Tugas-tugas guru tersebut adalah:

1. Teachers' activities involved in classroom instruction:

a. Teaching subject mater;

b. Teaching pupils to study

2. Teachers' activities involved in school and classroom management (exlusive of extracurricular activities).

3. Activities involved supervision of pupils' extra classroom activities.

4. Activities involving relationships with personnel of school staff.

5. Activities involving relationship with members of school community.

6. Activities concern with professional and personal achievement.

7. Activities in connection with school plant and supplies.

Unsur-unsur kompetensi guru yang terdapat dalam kurikulum college of education di Amerika Serikat ternyata sesuai sekali dengan rumusan kompetensi guru di Indonesia.

Grimmet dan Ratzaff (1986) membandingkan temuan riset di AS dan Kanada (Houston, 1990:558) tentang harapan dari MHS PPL, Guru Pamong, dan Dosen Pembimbing. Di kedua negara tersebut, guru pamong diharapkan berperan dalam dalam mendiskusi penampilan setelah latihan mengajar secara teratur dan agar guru pamong berperan secara langsung dalam keterampilan mengjar dan manajemen kelas. Guru pamong juga diharapkan untuk mengobservasi saat mahasiswa PPL berlatih mengajar dan memberikan masukan tentang efektivitas mengajar saat latihan.

Sebuah studi tentang diskusi dalam kegiatan pembimbingan PPL oleh guru pamong dan oleh dosen pembimbing dengan setelah latihan mengajar menunjukkan bahwa guru pamong berperan lebih besar dalam pertumbuhan motivasi mhs PPL dibandingkan dosen pemibimbing (Cuff. 1978). Hasil penelitian Copeland (1982) menunjukkan bahwa guru pamong memiliki dampak signifikan terhadap perilaku dan kompetensi guru pada mahasiswa PPL.

Penelitian tentang pengaruh PPL terhadap peningkatan kompetensi guru tidak terlalu banyak dilakukan. Salah satunya Novitasari (2013) mengkaji kesiapan mahasiswa menjadi tenaga pendidik diukur berdasarkan tingkat kualitas penguasaan kompetensi mengajar. Hasil penelitian menunjukkan bahwa terdapat pengaruh yang signifikan pelaksanaan Program Pengalaman Lapangan (PPL) terhadap kesiapan mahasiswa menjadi tenaga pendidik, dengan arah hubungan yang positif, pada mahasiswa prodi pendidikan ekonomi.

Permasalahan dalam PPL adalah ketidakterpenuhan harapan dan keinginan pihak-pihak yang terlibat seperti mahasiswa, guru pamong dan dosen pembimbing. Masalah komunikasi diantara pihak-pihak terkait merupakan masalah yang terjadi secara berulang. 
Adapun kegiatan yang dilakukan mahasiswa ketika PPL yaitu mengajar (melatih kompetensi pedagogik dan kompetensi profesional), melaksanakan tugas yang bersifat administrasi seperti kegiatan akademik seperti program semester, membuat jadwal, kesiswaan, dan agenda guru, mengikuti organisasi yang ada di sekolah dan melakukan bimbingan (berkonsultasi) dengan dosen luar biasa (pamong) dan juga dosen pembimbing baik masalah persiapan mengajar ataupun pelaksanaqan latihan mengajar serta melatih kompetensi kepribadian dan kompetensi sosial. Melalui kegiatan PPL ini mahasiswa memiliki bekal kompetensi guru yang diperlukan sebagai tenaga profesional kependidikan.

Berdasarkan paparan teori diatas dapat disimpulkan bahwa PPL menjadi faktor yang diduga mempunyai pengaruh dalam meningkatkan kompetensi guru pada mahasiswa sesuai dengan standar kompetensi dalam undang-undang.

\section{Landasan Pelaksanaan Kegiatan Program Pengalaman Lapangan}

Dasar landasan pelaksanaan kegiatan Program Pengalaman Lapangan bagi mahasiswa yang telah diatur dalam perundang-undangan dan ketentuan-ketentuan operasional menjadi landasan dalam melaksanakan kegiatan Program Pengalaman Lapangan di lingkungan UPI, yakni :

a. Undang-undang Nomor 20 tahun 2003 tentang Sistem Pendidikan Nasional.

b. Undang-undang Nomor 14 tahun 2005 tentang Guru dan dosen.

c. Keputusan Rektor UPI Nomor $2767 / \mathrm{H} 40 / \mathrm{KL} / 2008$ tentang Pembentukan Direktorat Akademik.

Program Pengalaman Lapangan bertujuan untuk mempersiapkan para mahasiswa sebagai tenaga kependidikan yang profesional melalui kegiatan latihan mengajar dan kegiatan kurikuler dan ekstra kurikuler di sekolah.

\section{Mekanisme Program Pengalaman Lapangan}

Mekanisme Program Pengalaman Lapangan dalam buku panduan Program Pengalaman Lapangan (2013:2) sebagai berikut :Sebelum mahasiswa mengikuti PPLwajib mengikuti pelatihan micro teaching. Waktu/jadwal untuk melakukan kegiatan orientasi, adaptasi, dan penampilan ditentukan oleh Dosen LB PPL/ Kepala Sekolah yang bersangkutan.

\section{Kompetensi Guru}

Kompetensi merupakan pengetahuan, keterampilan, dan nilai-nilai dasar yang direfleksikan dalam kebiasaan dan bertindak (perilaku) secara terus menerus. Kebiasaan berpikir dan bertindak secara konsisten dan terus menerus memungkinkan seseorang menjadi kompeten, dalam arti memiliki pengetahuan, keterampilan dan nilai dasar untuk melakukan sesuatu (Pusat Kurikulum Depdiknas, $2003: 3)$.

Pengertian kompetensi menurut E.Mulyasa (2008 : 26) mengatakan bahwa: "kompetensi merupakan komponen utama dari standar profesi di samping kode etik sebagai perilaku profesi yang ditetapkan dalam prosedur dan sistem pengawasan tertentu."
Pengertian kompetensi guru dalam Undangundang No.14 tahun 2005 pasal 1 butir 10 Pengertian kompetensi adalah "seperangkat pengetahuan, keterampilan, dan perilaku yang harus dimiliki, dihayati dan dikuasai oleh guru atau dosen dalam melaksanakan tugas keprofesionalan."

Berdasarkan uraian di atas bahwa kompetensi merupakan kemampuan dan keterampilan yang harus dimiliki oleh para mahasiswa sebagai calon guru dalam melaksanakan tugas keprofesionalannya.

Kompetensi Guru menurut Undang-undang No.14 tahun 2005 meliputi empat kompetensi yaitu pedagogik, profesional, kepribadian, dan sosial. Dalam penjelasan Peraturan Pemerintah No.19 tahun 2005 empat kompetensi yang harus dimiliki oleh seorang guru dan calon guru adalah sebagai berikut:

a. Kompetensi pedagogik

Kompetensi pedagogik merupakan kemampuan mengelola pembelajaran siswa yang meliputi pemahaman terhadap siswa, perencanaan dan pelaksanaan pembelajaran, evaluasi hasil belajar dan pengembangan siswa untuk mengaktualisasikan berbagai potensi yang dimiliki.

b. Kompetensi kepribadian

Kompetensi kepribadian merupakan kemampuan kepribadiannya yang mantap, stabil, dewasa, arif dan berwibawa, menjadi teladan bagi siswa dan berakhlak mulia.

c. Kompetensi profesional

Kompetensi profesional merupakan kemampuan penguasaan materi pembelajaran secara luas dan mendalam yang memungkinkannya membimbing siswa memenuhi standar nasional pendidikan.

d. Kompetensi sosial

Kompetensi sosial merupakan kemampuan pendidik sebagai bagian dari masyarakat untuk berkomunikasi dan bergaul secara efektif dengan siswa, sesama pendidik, tenaga kependidikan, orang tua/wali siswa dan masyarakat sekitar. (PP N0 19 Tahun 2005).

Dari berbagai pendapat tentang kompetensi guru sebagaimana di kutip di atas, penulis memilih yang paling komprehensif dan menyeluruh yaitu berdasarkan PP Nomor 15 tahun 2005.

\section{Kompetensi Pedagogik}

Kompetensi pedagogik merupakan kompetensi yang berperan penting untuk meningkatkan kemampuan peseta didik. Dalam penjelasan Peraturan Pemerintah No.19 tahun 2005 dijelaskan bahwa kompetensi pedagogik meliputi :

Berdasarkan Panduan PPL format untuk menilai kompetensi pedagogik terdapat dua alat yaitu: Pertama, instrumen untuk menilai RPP (kode F01). Kedua, instrumen untuk menilai tampilan latihan mengajar (kode F02). Berikut adalah unsurunsur yang terdapat dalam dokumen F01 untuk menilai rancangan program pembelajaran (RPP) :

(1) Rumusan Tujuan Pembelajaran (umum)/ yakni rumusan tujuan dalam RPP menggambarkan pencapaian : a. Standar Kompetensi Dasar; b. Aspek kognitif; c. Aspek afektif; dan d. Aspek psikomotor. 
(1) Penjabaran indikator yakni indikator dirumuskan berdasarkan: Aspek kompetensi (kognitif, afektif, dan psikomotor).

(2) Materi ajar disusun dengan cara : a. mengacu kepada indikator; b. sistematis; c. sesuai dengan pencapaian kompetensi; d. dirancang secara proporsional untuk satu standar kompetensi/kompetensi dasar.

(3) Langkah-langkah pembelajaran (skenario)yaitu skenario disusun : a. untuk setiap indikator; $b$. mencerminkan komunikasi guru-siswa yang berpusat pada siswa; c. menyiratkan dan/atau menyuratkan penerapan metode dan media pembelajaran; $d$.

(4) Pemilihan media pembelajaran disesuaikan: a. relevan dengari tuntutan standar kompetensi; $b$. relevan dengan sasaran indikator; c. kondisi kelas; d. disiapkan untuk mendukung perkembangan kondisi siswa,

(5) Rancangan evaluasi pembelajaran meliputi: a. mencantumkan bentuk dan jenis evaluasi; b. butir soal relevan dengan indikator; c. menerapkan tuntutan standar kompetensi; d. butir soal sesuai dengan tuntutan waktu secara proporsional.

Sementara untuk menilai latihan mahasiswa PPL dalam kegiatan proses pembelajaran digunakan instrumen F02. Berikut adalah unsur-unsur yang terdapat dalam dokumen F01 untuk menilai kompetensi pedagogik aspek penampilan mengajar atau melaksanakan pembelajaran terdiri dari :

1) Kemampuan membuka pelajaran

2) Sikap Praktikan dalam proses pembelajaran

3) Penguasaan Materi Pembelajaran

4) Implementasi dari langkah-langkah (skenario) pembelajaran

5) Penggunaan media pembelajaran

6) Evaluasi

7) Kemampuan menutup pembelajaran (Buku Panduan PPL; 2013:17-18)

\subsubsection{Kompetensi Profesional}

Pengertian profesional menurut Kamus Umum Bahasa Indonesia $(2001 ; 126)$ adalah "sifat sesuatu yang berkenaan dengan profesi, penampilan dalam menjalankan jabatan sesuai dengan tuntutan profesi, orang yang mempunyai kemampuan sesuai dengan tuntutan profesi". Selanjutnya Soetjipto dan Raflis Kosasi (2009 : 262) merinci ciri-ciri kompetensi profesional seorang guru adalah sebagai berikut:

c. Memahami materi ajar yang ada dalam kurikulum sekolah.

d. Dalam hal ini guru harus mampu untuk mengembangkan kurikulum sesuai dengan materi yang akan diajarkan.

e. Memahami struktur, konsep dan metode keilmuan yang menaungi atau koheren dengan materi ajar.

f. Guru harus mampu merancang dan memahami materi ajar sesuai dengan struktur, konsep dan metode keilmuannya.

g. Memahami hubungan konsep antar mata pelajaran terkait.

h. Guru harus mampu untuk menganalisis keterkaitan antar mata pelajaran dalam satu konsep. a. Menerapkan konsep-konsep keilmuan dalam kehidupan sehari-hari.

b. Guru harus mampu untuk mempraktekan teori dan memanfaatkannya dalam kehidupan seharihari.

Sementara itu untuk menilai kompetensi profesional mahasiswa PPL terdiri dari dua hal. Pertama kemampuan mahasiswa dalam merancang uraian materi pelajaran yang akan diajarkan dari sudut sistimatika dan proporsinya dan penyusunan soal untuk pos-tes yang tertulis pada RPP. Sedangkan dalam kegiatan proses pembelajaran digunakan instrumen F02 terdapat aspek yang dinilai berupa pemahaman mahasiswa PPL dalam hal struktur, konsep dan metode keilmuan yang menaungi atau koheren dengan materi ajar. Berikut adalah unsur-unsur yang terdapat dalam dokumen F02 pada buku Panduan PPL yang digunakan untuk menilai kompetensi profesional saal latihan penampilan mengajar atau melaksanakan pembelajaran: Mahasiswa PPL harus memahami struktur, konsep dan metode keilmuan yang menaungi atau koheren dengan materi ajar yang terdiri dari :

a. Kejelasan memposisikan materi ajar yang disampaikan dengan meteri lainnya yang terkait;

b. Kejelasan menerangkan dan tuntutan aspek kompetensi

c. Kejelasan dalam memberikan contoh / ilustrasisesuai dengan tuntutan aspek kompetensi;

d. Mencerminkan penguasaan materi ajar secara proporsional.

Dengan demikian apa yang ada dalam format penilaian PPL aspek kompetensi profesional telah sesuai dengan ketentuan PP Nomor 19 tahun 2005.

\subsubsection{Kompetensi Kepribadian}

Prof. Dr. Zakiah Daradjat (Djamarah,2005: 39)menyatakan bahwa kepribadian yang sesungguhnya adalah abstrak, sukar untuk dilihat atau diketahui secara nyata, yang dapat diketahui adalah penampilan dalam segi dan aspek kehidupan. Misalnya dalam tindakannya, ucapan, cara bergaul, berpakaian, dan dalam menghadapi setiap persoalan atau masalah baik yang ringan maupun yang berat. Kompetensi kepribadian yang tertuang dalam buku Pedoman PPL merupakan kompetensi yang mencerminkan kepribadian yang dimiliki amahasiswa calon guru Aspek kompetensi kepribadian yang dinilai dalam adalah sebagai berikut:

a. Kepemimpinan di dalam dan di luar kelas

b. Tanggung jawab terhadap tugas dari Guru Pamong PPL.

c. Stabilitas emosi pada saat penapilan mengajar di kelas maupun di luar kelas

d. Disiplin terhadap aturan yang berlaku dalam PPL

e. Sikap di dalam dan di luar kelas

f. Cara berbusana di dalam dan di luar kelas. Kompetensi kepribadian menurut penjelasan Peraturan Pemerintah No.19 tahun 2005 jelas lebih rinci dan menyeluruh dibandingkan dengan yang tertera pada panduan PPL. Namun demikian secara prinsip apa yang dipergunakan dalam menilai kompetensi kepribadian selama ini oleh PPL UPI sudah mencakup aspek kompetensi kepribadian menurut penjelasan Peraturan Pemerintah No.19 tahun 2005. 


\subsubsection{Kompetensi Sosial}

Kompetensi sosial selama ini digunakan oleh PPL UPI secara spesifik kerkandung dalam aspek konsep sosialisasi. Sosialisasi merupakan konsep berasal dari sosiologi. Sebagtaimana kita pahami bahwa Pendidikan merupakan ilmu terapan yang memiliki dua tiang ilmu yaitu Psikologi dan Sosiologi. Kaitannya dengan kompetensi guru aspek kompetensi sosial jelas sesungguhnya melekat pada pribadi guru.

\section{Hipotesis}

Berdasarkan penjelasan kerangka pemikiran dan permasalahan diatas, hipotesis dalam penelitian ini dirumuskan sebagai berikut:

a. Program Pengalaman Lapangan dapat meningkatkan kompetensi pedagogik pada mahasiswa Program Studi Pendidikan Akuntansi.

b. Program Pengalaman Lapangan dapat meningkatkan kompetensi profesional pada mahasiswa Program Studi Pendidikan Akuntansi.

c. Program Pengalaman Lapangan membina dan mengukur tingkat kompetensi kepribadian pada mahasiswa Program Studi Pendidikan Akuntansi.

d. Program Pengalaman Lapangan membina dan mengukur tingkat kompetensi sosial pada mahasiswa Program Studi Pendidikan Akuntansi.

\section{Metode Penelitian}

\section{Desain Penelitian}

Metode penelitian yang digunakan dalam penelitian ini adalah metode penelitian eksperimen. Bentuk eksperimen yang digunakan desain eksperimen semu (quasi eksperimental design). Dalam penelitian ini, bentuk desain eksperimen semu yang sesuai adalah desain kelompok eksperimen dengan pre-tes dan pos-tes tampa kelas kontrol karena semua anggota populasi mendapatkan perlakuan yang sama.

Pada desain ini hanya terdapat satu kelompok yaitu mahasiswa peserta PPL Program Studi Pendidikan Akuntansi angkatan 2009.

Paradigma desain penelitian kelompok eksperimen dan kontrol hanya dengan pascates seperti digambarkan dalam Uma Sekaran (2009: 209) sebagai berikut :

TABEL 3.1

Paradigma Penelitian Eksperimen PRE-TES dan POS-TES

\begin{tabular}{|l|c|c|c|}
\hline & $\begin{array}{c}\text { Skor PPL } \\
\text { Awal }\end{array}$ & Perlakuan & $\begin{array}{c}\text { Skor PPL } \\
\text { Akhir }\end{array}$ \\
\hline $\begin{array}{l}\text { Kelompok } \\
\text { eksperimen }\end{array}$ & $\rho_{1}$ & $\mathrm{X}$ & $\rho_{2}$ \\
\hline
\end{tabular}

Keterangan :

$X=$ Perlakuan yang diberikan (Program Pengalaman Lapangan )

$0_{1}=$ Hasil pengukuran (kompetensi guru) sebelum diberi perlakuan.

$\rho_{2}=$ Hasil pengukuran (kompetensi guru) setelah diberi perlakuan.
Penelitian eksperimen dengan kelompok eksperimen dengan pre-tes dan pos-tes tanpa kelas kontrol digunakan untuk menguji kebenaran hipotesis.

\section{Populasi dan Sampel}

Populasi sebagai sumber data dalam penelitian ini adalah mahasiswa pendidikan akuntansi tahun 2009 yang berjumlah 70 orang sesuai dengan dokumen yang bisa dikumpulkan dari semua sekolan yang dijadikan tempat latihan.

Adapun perhitungan untuk menetukan jumlah sampel siswa akan diteliti dengan menggunakan rumus Taro Yamane atau Slovin (Riduwan,2004:254) sebagai berikut:

$$
n=\frac{N}{M d^{2}+1}
$$

Dimana: $n=$ Jumlah sampel

$N=$ Jumlah populasi 142 siswa

$d^{2}=$ Presisi (ditetapkan 5\%)

Berdasarkan rumus tersebut jumlah sampel yang akan diteliti adalah sebagai berikut:

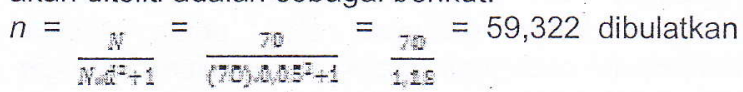
menjadi 60 mahasiswa.

Teknik pengumpulan data merupakan cara yang digunakan dalam penelitian ini adalah studi dokumentasi. Dokumen penilaian kompetensi guru dari guru pamong PPL/dosen luar biasa. Hal ini dikarenakan informasi atau data yang diperlukan dihasilkan selama proses pelaksanan latihan pada awal dan pada akhir PPL.

\section{Pengujian Hipotesis}

Hipotesis yang diajukan dalam penelitian ini adalah sebagai berikut :

Ho: $\mu_{2}=\mu_{2}$ Tidak ada perbedaan nilai kompetensi guru pada awal PPL dengan nilai kompetensi guru pada akhir PPL.

Ha: $\mu_{1} \neq \mu_{2}$ Ada perbedaan nilai kompetensi guru pada awal PPL dengan nilai kompetensi guru pada akhir PPL.

Pengujian hipotesis dilakukan menghitung uji beda rata-rata dengan menggunakan uji-t untuk mengetahui hasi atau peningkatan rata-rata nilai kompetensi guru di awal PPL sebagai nilai pre-tes dengan nilai kompetensi guru pada mahasiswa di akhir PPL sebagai nilai pos-tes.

$$
\begin{aligned}
& \text { Pengujian Hipotesis } \\
& \mathrm{H}_{\mathrm{a}} \text { : thitune }<\mathrm{t}_{\mathrm{tabe}}
\end{aligned}
$$

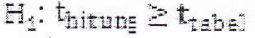

Mencari tabe dengan taraf signifikansi $5 \%$ atau $\alpha=$ 0,05 dimana:

$F_{0}:$ Tidak ada perbedaan nilai pre-tes dengan pos-test PPL

$F_{1}$ : Terdapat perbedaan nilai pre-tes dengan pos-test PPL 
Hasil dan Pembahasan

Deskripsi Hasil Penelitian

1. Kompetensi Pedagogik.

Perolehan nilai kompetnsi pedagogik oleh mahasiswa PPL Program Studi Pendidikan Akuntansi pada awal melaksanakan PPL berarti kompetensi yang dimiliki masih sepenuhnya hasil dari pendidikan berbasis kampus karena merupakan tampilan pertama dari perilaku mahasiswa dalam hal kompetensi pedagogik. Sedangkan nilai kompetensi pedagogik pada saat-saat terakhir pelaksanaan PPL bermakna sebagai hasil proses latihan dan bimbingan dari pembimbing PPL baik dosen luar biasa (guru pamong) maupun dari dosen pembimbing dari universitas. Tabel berikut merupakan gambaran capaian awal dan akhir PPL dari kompetensi pedagogik mahasiswa PPL:

Tabel 4.1

Nilai Kompensi PedagogikMahasiswaPPL Pendidikan Akuntansi

\begin{tabular}{|l|l|c|c|c|}
\hline No. & Keterangan & \multicolumn{2}{|c|}{$\begin{array}{c}\text { Nilai } \\
\text { Kompetensi }\end{array}$} & \multirow{2}{*}{$\begin{array}{c}\text { Rata-rata } \\
\text { Perbedaan } \\
\text { Nilai (Gain) }\end{array}$} \\
\cline { 3 - 4 } & $\begin{array}{c}\text { Pre- } \\
\text { tes }\end{array}$ & $\begin{array}{c}\text { Pos- } \\
\text { tes }\end{array}$ & \\
\hline 1 & $\begin{array}{l}\text { Rata-rata } \\
\text { nilai }\end{array}$ & 3,02 & 3,80 & 0,70 \\
\hline 2 & \multicolumn{2}{|l|}{ Standar Deviasi dari Gain } & 0.13029 \\
\hline
\end{tabular}

Berdasarkan tabel di atas, rata-rata nilai kompetensi pedagogik mahasiswa pada awal PPL atau pertama kali berlatih membuat RPP berikut segala kelengkapannya termasuk soal untuk penilaian hasil belajar siswa, latihan mengajar yang terdiri dari kegiatan awal, kegiatan inti dan kegiatan akhir hanya mencapai nilai 3,02. Namun demikian pada akhir pelaksanaan PPL terjadi lonjakan pencapai nilai kompetnsi paedagogis hingga mencapai 3,80. Nilai ini merupakan kelas interval tertinggi dalan skala interval 1-4.

a. Melakukan uji beda rata-rata before- after Berdasarkan hasil perhitungan untuk menguji hipotesis penelitian diperoleh $t$ hitung sebesar 45,55 dan dengan taraf kepercayaan $0,95 \% \mathrm{t}$ tabelnya adalah 1,67 .

b. Menguji Hipotesis

Hipotesis yang diajukan dalam penelitian ini adalah sebagai berikut :

1) $\mathrm{Ho}_{\mathrm{a}}: u_{2}=\mu_{2}$ Tidak ada perbedaan nilai kompetensi guru dimensi kompetensi pedagogik pada awal PPL dengan nilai kompetensi guru pada akhir PPL.

2) Ha: $\mu_{2} \neq \mu_{2}$ Ada perbedaan nilai kompetensi guru dimensi kompetensi pedagogik pada awal PPL dengan nilai kompetensi pedagogik pada akhir PPL.

Dari hasi uji beda rata-rata antara sebelum perlakuan dengan sesudah perlakuan dalam kuasi eksperimen adalah sebagai berikut: Nilai $t$ hitung adalah 43,55 . Sedangkan nilai $t$ table pada taraf kepercayaan $0,95 \%$ didapat $t_{59.0,95}=1.67$. Dengan demikian $t_{\text {nitung }}$ lebih besar dari $t$ tabel sehingga dapat disimpulkan bahwa hipotesis nol ditolak. Dengan demikian hipotesis diterima berarti bahwa PPL dapat meningkatkan kompetensi pedagogik mahasiswa.
2. Kompetensi Profesional.

Perolehan nilai kompetnsi profesional oleh mahasiswa PPL Program Studi Pendidikan Akuntansi pada awal melaksanakan PPL berarti kompetensi yang dimiliki masih sepenuhnya hasil dari pendidikan berbasis kampus dalam hal penguasaan materi bidang studi dan pengembangannya untuk tujuan pembelajaran. Tampilan pertama dari kompetensi profesional akan terlihat dari dokumen tertulis seperti RPP dan dari soal latihan atau poses-tes serta dari penguasaan meteri saat latihan mengajar. Sedangkan nilai kompetensi profesional pada saat-saat terakhir pelaksanaan PPL merupakan akumulasi dari proses pemantapan penguasaan materi bahan ajar berikut pengembangannya bermakna sebagai hasil proses latihan dengan boleh jadi ada masukan dari pembimbing PPL. Tabel berikut merupakan gambaran capaian awal dan akhir PPL dari kompetensi professional mahasiswaPPL:

Tabel 4.2

Nilai Kompensi ProfesionalMahasiswaPPL Pendidikan Akuntansi

\begin{tabular}{|c|c|c|c|c|}
\hline \multirow[t]{2}{*}{ No. } & \multirow[t]{2}{*}{ Keterangan } & \multicolumn{2}{|c|}{$\begin{array}{c}\text { Nilai } \\
\text { Kompetensi }\end{array}$} & \multirow[t]{2}{*}{$\begin{array}{l}\text { Perbedaan } \\
\text { Nilai (Gain) }\end{array}$} \\
\hline & & $\begin{array}{l}\text { Pre- } \\
\text { tes }\end{array}$ & $\begin{array}{l}\text { Pos- } \\
\text { tes }\end{array}$ & \\
\hline 1 & $\begin{array}{c}\text { Rata-rata } \\
\text { nilai }\end{array}$ & 2,71 & 3,86 & 0,74 \\
\hline 2 & \multicolumn{3}{|c|}{ Standar Deviasi } & 0,10833 \\
\hline
\end{tabular}

Berdasarkan tabel di atas, rata-rata nilai kompetensi profesional mahasiswa pada awal PPL atau pertama kali berlatih membuat RPP berikut segala kelengkapannya termasuk soal untuk penilaian hasil belajar siswa, latihan mengajar yang terdiri dari kegiatan awal, kegiatan inti dan kegiatan akhir hanya mencapi nilai 2,71. Namun demikian pada akhir pelaksanaan PPL terjadi Ionjakan pencapai nilai kompetnsi professional hingga mencapai 3,86. Nilai ini merupakan kelas interval kategori tertinggi dalan skala interval 1-4.

a. Melakukan uji beda rata-rata before- after

Berdasarkan hasil perhitungan untuk menguji hipotesis penelitian diperoleh $t$ hitung sebesar 45.62 dan dengan taraf kepercayaan $0,95 \% \mathrm{t}$ tabelnya adalah 1,67.

b. Menguji Hipotesis

Hipotesis yang diajukan dalam penelitian ini adalah sebagai berikut :

1) $\mathrm{Ho}_{2}: u_{2}=$ Tidak ada perbedaan nilai kompetensi guru dimensi kompetensi profesional pada awal PPL dengan nilai kompetensi profesional pada akhir PPL.

2) Ha: $\mu_{2} \neq u_{2}$ Ada perbedaan nilai kompetensi guru dimensi kompetensi profesional pada awal PPL dengan nilai kompetensi profesional pada akhir PPL.

Dari hasi uji beda rata-rata antara sebelum perlakuan dengan sesudah perlakuan dalam kuasi eksperimen adalah sebagai berikut: Nilai $t$ hitung adalah 45,62. Sedangkan $t$ table pada taraf kepercayaan $0,95 \%$ didapat $t_{59.0,95}=1.67$. Dengan demikian thitung lebih besar dari $t$ tabel sehingga dapat disimpulkan bahwa hipotesis nol ditolak. 
Dengan demikian hipotesis diterima berarti bahwa PPL dapat meningkatkan kompetensi pedagogik mahasiswa.

1. Kompetensi Kepribadian

Teknik pengumpulan data dalam peneliatian ini berupa studi dokumentasi dan sumber data yang dimiliki tidak ada penilaian pre-tes terhadap kompetensi kepribadian. Dengan ungkapan lain, penilaian oleh guru pamong terhadap kompetensi kepribadian terhadap mahasiswa PPL Program Studi Pendidikan Akuntansi tidak dilakukan pada awal pelaksanaan PPL, melainkan hanya pada akhir PPL. Hal ini merupakan kebijakan dari Direktorat Akademik UPI melalui Divisi P2JK. Selain berdasar ketentuan administratif sebagai mana tertulis di buku Panduan PPL pasti ada argumentasi akademis mengenai penilain kompetensi kepribadian. Secara sosiologis kepribadian seseorang itu dipengaruhi oleh norma dan nilai yang ada di lingkungan individu. Hal ini boleh jadi menjadi pertimbangan lembaga UPI sebagai sebuah LPTK belum membuat kebijakan adanya penilaian kompetensi guru aspek kompetensi kepribadian. Tabel berikut merupakan gambaran capaian awal dan akhir PPL dari kompetensi kepribadian mahasiswaPPL:

Tabel 4.3

Nilai Kompensi Kepribadian MahasiswaPPL Pendidikan Akuntansi

\begin{tabular}{|c|c|c|c|}
\hline No. & Keterangan & $\begin{array}{c}\text { Nilai } \\
\text { Kompetensi } \\
\text { Kepribadian }\end{array}$ & $\begin{array}{c}\text { Perbedaan } \\
\text { Nilai (Gain) }\end{array}$ \\
\hline 1 & $\begin{array}{c}\text { Rata-rata } \\
\text { nilai }\end{array}$ & 3,81 & Tidak ada \\
\hline & & & \\
\hline
\end{tabular}

Berdasarkan tabel di atas, pencapaian nilai kompetensi kepribadian hingga mencapai 3,81 merupakan kelas interval kategori tertinggi dalan skala interval 1-4. Dengan demikian capaian akhir kompetensi guru aspek kompetensi kepribadian dari mahasiswa Program Studi Pendidikan Akuntansi tergolong sangat memuaskan atau jika menggunakan standar Yudicium termasuk dengan pujian.

Oleh karena hanya ada satu nilai kompetensi kepribadian di akhir PPL maka tidak bisa dilakukan langkah-langkah perhitungan statistik sebagaimana pada kompetensi paedagogis dan kompetensi profesional.

\section{Kompetensi Sosial}

Sama seperti kompetensi kepribadian, penilaian oleh guru pamong terhadap kompetensi sosial dari mahasiswa PPL Program Studi Pendidikan Akuntansi tidak dilakukan pada awal pelaksanaan PPL melainkan hanya pada akhir PPL. Hal ini juga merupakan kebijakan dari Direktorat Akademik UPI melalui Divisi P2JK paling tidak sampai saat ini. Selain berdasar ketentuan administratif sebagai mana tertulis di buku Panduan PPL, pasti ada argumentasi akademis mengenai penilain kompetensi social hnaya dilakukan pada akhir PPL. Tabel berikut merupakan gambaran capaian awal dan akhir PPL dari kompetensi sosial mahasiswaPPL:
Tabel 4.4

Nilai Kompensi Kepribadian MahasiswaPPL Pendidikan Akuntansi

\begin{tabular}{|c|c|c|c|}
\hline No. & Keterangan & $\begin{array}{c}\text { Nilai } \\
\text { Kompetensi } \\
\text { Kepribadian }\end{array}$ & $\begin{array}{c}\text { Perbedaan } \\
\text { Nilai (Gain) }\end{array}$ \\
\hline 1 & $\begin{array}{c}\text { Rata-rata } \\
\text { nilai }\end{array}$ & 3,82 & Tidak ada \\
\hline & & & \\
\hline
\end{tabular}

Berdasarkan tabel di atas, pencapaian nilai kompetensi sosial hingga mencapai 3,82 merupakan kelas interval kategori tertinggi dalan skala interval 1-4. Dengan demikian capaian akhir kompetensi guru aspek kompetensi sosial dari mahasiswa Program Studi Pendidikan Akuntansi tergolong sangat memuaskan atau jika menggunakan standar yudicium termasuk dengan pujian.

Oleh karena hanya ada satu nilai kompetensi sosial hanya ada satu kali di akhir PPL maka tidak bisa dilkukan langkah-langkah perhitungan statistik selain dari angka nilai rata-rata tidak seperti pada kompetensi paedagogis dan kompetensi profesional.

\section{Pembahasan Hasil Penelitian}

Berdasarkan hasil pengolahan data penelitian yang telah diuraikan di atas penulis akan melakukan pembahasan hasil penelitian.

1. Kompetensi Pedagogik

Dari hasi uji perbedaan atau gain antara nilai sebelum perlakuan dengan sesudah perlakuan dalam kuasi eksperimen adalah sebagai berikut: Nilai $t$ hitung adalah 82,23. Sedangkan nilai $t$ table pada taraf kepercayaan $0,95 \%$ didapat $t_{59.0,95}=1.67$. Dengan demikian thitung lebih besar dari $t$ tabel sehingga dapat disimpulkan bahwa hipotesis nol ditolak. Dengan demikian hipotesis diterima berarti bahwa PPL dapat meningkatkan kompetensi pedagogik pada mahasiswa PPL.

Ditinjau dari rata-rata nilai kompetensi pedagogik yang telah mencapai angka 3,02 dari rentang nilai 1 - 4. Hal ini berarti bahwa kompetensi pedagogik pada mahasiswa Program Studi Pendidikan Akuntansi tergolong sangat memuaskan meski pun itu pada tampilan perdana dalam latihan PPL. Makna lain dari nilai kompetensi pedagogik pada awal PPL menunjukkan bahwa pendidikan kompetensi guru yang selama ini dilakukan di kampus UPI oleh antara lain para dosen PBM di Program Studi Pendidikan Akuntansi cukup efektif dan sangat memuaskan. Tentu saja hal ini tidak berarti cukup puas dengan capaian yang ada. Semua pihak harus bertekad untuk meningkatkan kinerja agar pemdidikan calon guru yang berbasis kampus harus ditingkatkan mutunya.

2. Kompetensi Profesional

Dari hasi uji perbedaan atau gain antara nilai sebelum perlakuan dengan sesudah perlakuan dalam kuasi eksperimen adalah sebagai berikut: Nilai $t$ hitung adalah 82,23. Sedangkan nilai $t$ table pada taraf kepercayaan $0,95 \%$ didapat $t_{59.0,95}=1.67$. Dengan demikian $t_{\text {hitung }}$ lebih besar dari $t$ tabel 
Hicks, C.R. (1982) Fundamental Concept in the Design of Experiments, New York. Holt, Rinehart and Winston.

Hindayanti. N. (2011). Pengaruh Program Latihan Profesi terhadap Kompetensi Mengajar Mahasiswa Program Studi Pendidikan Akuntansi. Skripsi. Tidak diterbitkan.

Houston, W.R., (1990). Handbook of Research on Teacher Education. New York. McMillan Publishing Company.

Kunandar. 2008. Guru Profesional Implementasi Kurikulum Tingkat Satuan Pendidikan (KTSP) Sukses dalam Sertifikasi Guru. Jakarta : PT Rajagrafindo Persada.

Mulyasa, E. (2008). Standar Kompetensi dan Sertifikasi Guru. Bandung : PT Remaja Rosdakarya.

Nasution, S. (2010). Didaktik Asas-asas Mengajar. Jakarta : Bumi Aksara.

Novitasari, F. et al. (2009). Pengaruh Program Pengalaman Lapangan terhadap Kesiapan Mahasiswa Prodi Ekonomi FKIP UNS untuk menjadi Tenaga Pendidik. Jurnal Penelitian UNS, Vol 1 No 2.

Riduwan.(2008). Dasar-dasar Statistika. Bandung: alfabeta

Safitri, Ade (2013) Pengaruh Persepsi Mahasiswa PPL tentang Proses Belajar Mengajar terhadap Pemahaman Tugas dan Fungsi Guru. Tesis Pasca Sarjana UPI. Tidak diterbitkan
Sekaran, Uma. (2006). Metode Penelitian untuk Bisnis Edisi 4 Buku 2. Jakarta : Salemba Empat.

Soetjipto dan Raflis Kosasi. (2009). Profesi Keguruan. Jakarta : PT Rineka Cipta.

Syaiful Bahri Djamarah. (2005). Guru dan Anak didik dalam Interaksi Edukatif. Jakarta :PT.Rineka Cipta.

Uzer Usman. (2002). Menjadi Guru Profesional. Bandung: PT Remaja Rosdakarya.

Wardani K dan Anah Suhaenah Suparno. (1994). Program Pengalaman Lapangan. Jakarta : DEPDIKBUD

Sumber Dokumen:

Universitas Pendidikan Indonesia. (2006). Kurikulum Ketentuan Pokok dan Struktur Program. Bandung : Universitas Pendidikan Indonesia.

Universitas Pendidikan Indonesia. (2013). Panduan Program Pengalaman Lapangan (PPL). Bandung : Universitas Pendidikan Indonesia.

Rektor Universitas Pendidikan Indonesia. (2008). Rektor Universitas Pendidikan Indonesia Nomor: $2767 / \mathrm{H} 40 / \mathrm{KL} / 2008$ Tentang Pembentukan Direktorat Akademik Universitas Pendidikan Indonesia. Bandung: Rektor Universitas Pendidikan Indonesia.

Undang-undang Republik Indonesia Nomor 14 Tahun 2005 Tentang Guru dan Dosen. Jakarta : Indonesia Legal Center Publishing. 